Original Research Paper

\title{
The Use of Jayanti (Sesbania sesban) Molluscicide in Overcoming Golden Snail, Pest of Rice Plant in The Village of Bunut Baok, Central Lombok.
}

\author{
Suripto $^{1}$, Erin Ryantin Gunawan ${ }^{2}$, Evy $_{\text {Aryanti }}{ }^{3}$

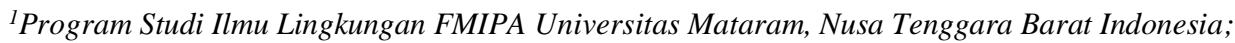 \\ ${ }^{2}$ Program Studi Kimia FMIPA Universitas Mataram, Nusa Tenggara Barat Indonesia; \\ ${ }^{3}$ Program Studi Biologi FMIPA Universitas Mataram, Nusa Tenggara Barat Indonesia;
}

https://doi.org/10.29303/jpmpi.v3i2.948

Sitasi: Suripto, E.R. Gunawan \& E. Aryanti (2021). The Use of Jayanti (Sesbania sesban) Molluscicide in Overcoming Golden Snail, Pest of Rice Plant in The Village of Bunut Baok, Central Lombok.. Jurnal Pengabdian Magister Pendidikan IPA, 4(3)

\section{Article history}

Received: 28 Agustus 2021

Revised: 8 September 2021

Accepted: 9 September 2021

*Corresponding Author:

Suripto

Study Program of

Environmental Sciences

Faculty of Mathematics and

Natural Sciences

University of Mataram

Email: suriptobio@unram.ac.id

\begin{abstract}
As a result of the attack golden snails, rice production declined to $30 \%$ in some places in the province of West Nusa Tenggara. Application of science and technology activities for the community (IbM) to address the problem of golden snail pest have been conducted in The Village of Bunut Baok, Central Lombok. IbM program conducted by subject matter covers characteristics of jayanti plant (Sesbania sesban) and its cultivation method, characteristics of golden snail species that is pests of the rice plant, how to prepare and manufacture of jayanti molluscicide, and its application to control rice pest snails. The methods used include lecture, discussion, demonstration and practice. IbM activity followed by 12 members of Farmers Group Mohon Petunjuk Bunut Baok Village. The results of the practice is that the use of 1 ppm solution jayanti leaf can be lethal $48 \%$ to $84 \%$ of golden snail population. Other results achieved are covering the growing appreciation of farmers to plant jayanti, increasing farmers' knowledge and skills in identifying plants jayanti, skilled to make jayanti molluscicide, and its use to control rice pest golden snails.
\end{abstract}

Keywords: golden snail, Jayanti plant (Sesbania sesban); molluskicides; The Village of Bunut Baok.

mengalami kegagalan panen padi akibat serangan keong mas.

Berbagai langkah penanggulangan keong mas di sawah padi telah dilakukan oleh petani, baik secara mekanik, biologis maupun secara kimiawi. Namun demikian, hasil-hasilnya dirasakan masih kurang efektif. Di Jawa Barat misalnya, penggunaan molusisida dari bahan kimia sintetik, seperti Brestan sudah dilarang karena selain dapat mematikan tanaman padi juga dapat mematikan ikan-ikan di kolam yang airnya berasal dari irigasi sawah, sedangkan keong mas masih tetap hidup (Suripto, 2019 $)$. 
Pengendalian keong mas secara mekanik dengan memasang tonggak-tonggak untuk untuk memerangkap telur keong mas dan pemungutan keong mas langsung oleh petani dirasakan kurang praktis, terutama untuk sawah padi yang sangat luas. Pengendalian keong mas secara biologis, seperti melepaskan hewan itik yang pernah dilakukan di Provinsi Jawa Barat dan melepaskan hewan-hewan ternak babi seperti yang pernah dilakukan Provinsi Bali juga tidak praktis, dan hanya dapat dilakukan pada lahan padi yang sudah dipanen atau pada lahan sebelum ditanami padi (Suripto, 2018).

Pengendalian hama keong mas di sawah padi juga telah dilakukan oleh petani di Desa Bunut Baok, baik secara mekanik, biologis maupun kimiawi. Namun demikian, hasil-hasilnya dirasakan masih kurang efektif. Masyarakat petani di daerah tersebut saat ini hanya pasrah dan belum memiliki pengetahuan untuk memilih molusisida yang aman lingkungan.

Sebenarnya, bila masyarakat petani di daerah tersebut mengetahui dan terampil untuk memilih, membuat dan mengaplikasikan bahan moluisida dari tumbuhan yang telah terbukti selektif untuk mengendalikan hama keong mas, maka masalah serangan keong mas terhadap tanaman padi di daerah tersebut akan dapat teratasi. Sehingga dengan demikian produktivitas padi sebagai komoditi unggulan di daerah tersebut akan dapat dipertahankan dan bahkan penghasilannya meningkat drastis karena berkurangnya kost untuk pengendalian. Tumbuhan sumber molusisida alami yang dimaksud adalah tanaman jayanti \{Sesbania sesban (L.) Merr.\} (Magnoliopsida: Fabaceae). Saat ini jenis tumbuhan tersebut di Desa Bunut Baok khususnya dan di Pulau Lombok pada umumnya tidak banyak dibudidayakan oleh para petani.

Hasil-hasil penelitian seleksi, evaluasi dan pengembangan kinerja anti moluska dari tanaman jayanti (S. sesban) telah dicoba melalui program penerapan ilmu dan teknologi bagi masyarakat (IbM) petani padi untuk mengendalikan keong mas hama tanaman padi di Desa Bunut Baok Kecamatan Praya Kabupaten Lombok Tengah Provinsi Nusa Tenggara Barat. Tujuan dari kegiatan IbM tersebut adalah untuk meningkatkan apresiasi petani terhadap tanaman jayanti, meningkatkan pengetahuan dan keterampilan petani dalam pembuatan dan penggunaan molusisida bahan alam dari tanaman jayanti untuk mengendalikan keong mas hama tanaman padi.

\section{Metode}

Pelaksanaan $\left(\mathrm{I}_{b} \mathrm{M}\right)$ dilakukan dengan menggunakan pendekatan TOT (training of trainer), yaitu penyuluhan dan pelatihan bagi kelompok petani. Khalayak petani sebagai sasaran kegiatan adalah perwakilan petani dari setiap wilayah lingkungan (setingkat dusun) di Desa Bunut Baok Lombok Tengah. Para wakil petani tersebut selanjutnya akan menjadi tutor bagi para anggota masing-masing kelompok tani setiap lingkungan. Materi kegiatan yang diberikan adalah ciri taksonomi dan ekologis tanaman jayanti, budidaya tanaman jayanati, teknologi produksi dan aplikasi molusisida yang feasible dari tanaman jayanti untuk mengendalikan keong mas hama tanaman padi

Kegiatan IbM ini dilakukan dalam dua sesi, yaitu sesi teori dan sesi praktek. Dalam sesi teori. Metode yang digunakan adalah ceramah (media: diktat, papan tulis, dan LCD disediakan oleh tim) dan diskusi. Penyampaian materi juga diarahkan untuk meningkatkan apresisiasi petani terhadap tanaman jayanti sebagai sumber molusisida. Dalam sesi praktek, introduksi teknologi produksi dan aplikasi molusisida asal tanaman jayanti bagi petani diberikan dengan menggunakan metode demonstrasi dan praktek lapangan.

\section{Hasil dan Pembahasan}

\section{Daya Anti Moluska dari Daun Jayanti Terhadap Keong Mas Hama Tanaman Padi Di Desa Bunut Baok Lombok Tengah}

Uji coba daya anti moluska dari daun jayanti terhadap keong mas hama tanaman padi dilakukan dalam 10 unit ulangan percobaan oleh kelompok tani di Desa Bunut Baok Lombok Tengah. Bahan molusisida dari daun jayanti yang digunakan bervariasi menurut lama waktu penyimpanan larutan daun diaplikasikan. Mortalitas keong mas diamati dalam dua periode aplikasi, 1) 24 jam dan 2) 48 jam pendedahan keong mas dalam larutan. Variasi konsentrasi larutan daun jayanti yang digunakan adalah 0 ppm sebagai kontrol dan 1 ppm (dari 1 gram kering daun dalam 1000 liter air) larutan daun jayanti.

Hasil menunjukkan, bahwa perlakuan dengan 1(satu) ppm larutan daun jayanti yang diaplikasikan 
secara langsung dapat mematikan $54 \%$ populasi keong mas setelah 24 jam hingga $84 \%$ populasi keong mas setelah 48 jam perlakuan. Namun demikian, prosentase kematian keong mas ini menjadi lebih rendah bila larutan jayanti tersebut sebelumnya disimpan terlebih dahulu selama 24 jam sebelum diaplikasikan (Gambar 1).

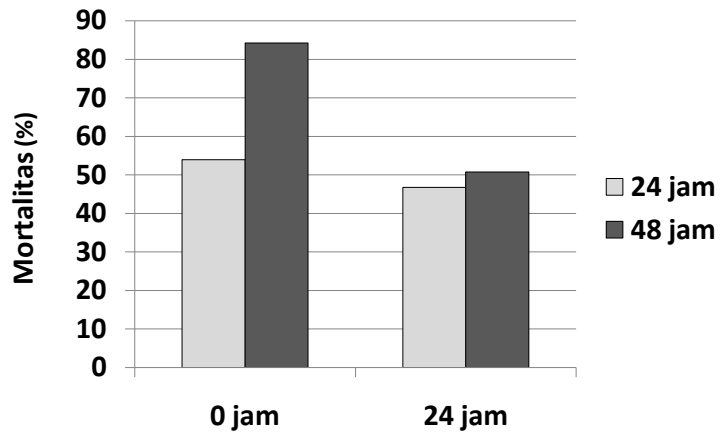

Lama waktu simpan sebelum aplikasi (jam)

Gambar 1. Mortalitas keong mas pada perlakuan $1 \mathrm{ppm}$ larutan daun Jayanti (S. sesban)

Bioaktivitas anti moluska dari larutan daun jayanti menurun karena kandungan aktifnya berupa saponin mengalami degradasi. Menurut Suripto (2011), kandungan aktif anti moluska dari tanaman jayanti dalam bentuk larutan daunnya akan menurun drastis setelah penyimpanan 24 jam sebelum diaplikasikan. Aktivitas anti moluska dari tanaman jayanti juga nyata menurun setelah penyimpanan selama satu bulan dalam bentuk pasta ekstrak. Demikian pula aktivitas anti moluska dari tanaman ini akan menurun setelah penyimpanan selama satu tahun dalam bentuk serbuk kering daunnya.

Berdasarkan hasil dan keterangan tersebut di atas, maka penggunaan molusisida dari tanaman jayanti dalam bentuk larutan sebaiknya langsung diaplikasikan tanpa disimpan terlebih dahulu. Bila diperlukan adanya penyimpanan bahan molusisida dari tanaman jayanti ini, maka penimpanan sebaiknya dilakukan terhadap bahan dalam bentuk serbuk kering daun untuk penyimpanan hingga maksimal satu tahun atau dalam bentuk pasta ekstrak untuk penyimpanan maksimal satu bulan.

\section{Pengetahuan dan Keterampilan Petani dalam Produksi dan Aplikasi Molusisida Jayanti}

Berdasarkan hasil pre-test diketahui, bahwa sebelum kegiatan IbM ini dilaksanakan, para petani di Desa Bunut Baok Lombok Tengah belum mengetahui dan belum memiliki keterampilan dalam membuat dan mengaplikasikan bahan molusisida dari tanaman jayanti untuk mengendalikan keong mas hama tanaman padi. Setelah mengikuti kegiatan IbM ini, petani di Desa Bunut Baok Lombok Tengah memiliki kompetensi untuk mengidentifikasi tanaman jayanti, membuat dan mengaplikasikan bahan molusisida dari tanaman jayanti untuk mengendalikan keong mas hama tanaman padi (Tabel 1).

Tabel 1. Prosentase jumlah peserta menurut nilai kompetensi pembuatan dan aplikasi bahan molusisida dari tanaman jayanti untuk pengendalian keong mas hama tanaman padi pada kegiatan IbM Petani Padi yang Menghadapi Hama Keong Mas Di Desa Bunut Baok Lombok Tengah.

\begin{tabular}{lccc}
\hline Kompetensi & \multicolumn{3}{c}{ Rentang Nilai (Skala 1-4) } \\
\cline { 2 - 4 } & $\begin{array}{l}2<\mathrm{x}<3 \\
\text { (Kurang) }\end{array}$ & $\begin{array}{l}3<\mathrm{x}<4 \\
\text { (Sedang) }\end{array}$ & $\begin{array}{c}4 \\
\text { (Baik) }\end{array}$ \\
\hline $\begin{array}{l}\text { Idensifikasi } \\
\text { jenis tanaman } \\
\text { jayanti }\end{array}$ & $8,33 \%$ & $16,67 \%$ & $75 \%$ \\
\hline $\begin{array}{l}\text { Koleksi dan } \\
\text { pengolahan } \\
\text { bahan }\end{array}$ & $0 \%$ & $16,67 \%$ & $83,33 \%$ \\
\hline $\begin{array}{l}\text { Teknik } \\
\text { aplikasi bahan } \\
\text { molusisida }\end{array}$ & $8,33 \%$ & $8,33 \%$ & $83,33 \%$ \\
\hline
\end{tabular}

Kompetensi petani yang nyata dapat ditingkatkan dari hasil kegiatan IbM tersebut adalah meliputi kemampuan mengidentifikasi jenis tanaman jayanti, menseleksi ukuran dan usia tanaman jayanti yang cocok untuk dikoleksi daunnya, terampil mongering-anginkan daun jayanti, membuat larutan dan mengaplikasikannya dalam skala percobaan terhadap keong mas hama tanaman padi. Pemahaman petani tentang jenis keong mas yang merupakan hama tanaman padi sangat diperlukan, agar langkah pengendalian oleh petani dapat dengan tepat mengenai sasaran.

Di Indonesia keong mas yang menjadi hama tanaman padi teridentifikasi sebagai Pomacea canaliculata, dengan ciri utama warna cangkangnya kuning kusam, konde cangkangnya pendek, dan rumpun telurnya berwarna merah 
seperti buah murbai sehingga banyak petani yang menyebutnya keong murbai. Terdapat keong mas lain yang juga dapat dijumpai di Indonesia tetapi tidak menjadi hama terhadap tanaman padi, yang teridentifikasi sebagai Pomacea sp. (berbeda jenis dengan $P$. canaliculata) dengan ciri warna cangkangnya kuning cerah, konde cangkangnya tinggi, dan rumpun telurnya berwarna putih (Munandar, 2013).

Untuk meningkatkan selektivitas dan efektivitas pengendalian keong hama tanaman padi, para petani juga perlu memiliki pengetahuan tentang spektrum tanaman inang dari keong mas tersebut. Selain padi, tanaman lain yang dapat diserang oleh keong mas adalah tanaman kangkung, dan semai tanaman jeruk (Mahfud, 2014 dalam Suripto, 2019 ). Terhadap berbagai kultivar tanaman padi, keong mas menunjukkan kesukaan dan prefalensi yang tidak berbeda nyata menurut variasi kultivar tanaman padi tersebut, seperti yang telah diamati pada kultivar-kultivar padi Cibogo, Cigeulis dan Ciherang (Suripto, 2009).

Pengetahuan petani tentang stabilitas anti moluska dari bahan tanaman juga sangat diperlukan agar dalam pembuatan dan penggunaan atau aplikasi bahan molusisida dari tanaman jayanti diperoleh hasil yang baik. Ujia hayati dalam skala laboratorium tentang stabilitas anti moluska dari tanaman jayanti terhadap keong mas telah dilakukan oleh Suripto et al. (2021).

Komponen aktif anti moluska dari daun $S$. sesban, dalam hal ini golongan saponin triterpen cukup stabil selama penyimpanan dalam bentuk ekstrak untuk selama satu bulan, namun tidak stabil selama penyimpanan dalam bentuk simplisia untuk selama satu tahun, yang menyebabkan bioaktivitasnya menurun dan menjadi tidak aktif lagi setelah dilarutkan dalam air selama 24 jam (Gambar 2).

Pada laporan lain juga dikemukakan, bahwa kandungan senyawa dari golongan saponin triterpen akan stabil selama tidak dalam larutan dengan air, tetapi bioaktivitasnya akan segera hilang setelah sekurang-kurangnya 24 jam berada dalam air (Francis et al., 2012; Suripto, 2019).

Berdasarkan hasil-hasil tersebut dapat direkomendasikan, bahwa penyimpanan simplisia daun jayanti sebelum diekstraksi sebaiknya tidak melebihi satu tahun, sedangkan penyimpanan bentuk ekstrak sebelum digunakan tidak melebihi satu bulan. Komponen aktif anti moluska dari daun jayanti, dalam hal ini saponin triterpen adalah tidak stabil dalam air. Selama aplikasi setelah 24 jam kandungan bahan anti moluska ekstrak tersebut tidak aktif lagi (tidak toksik letal terhadap keong mas).

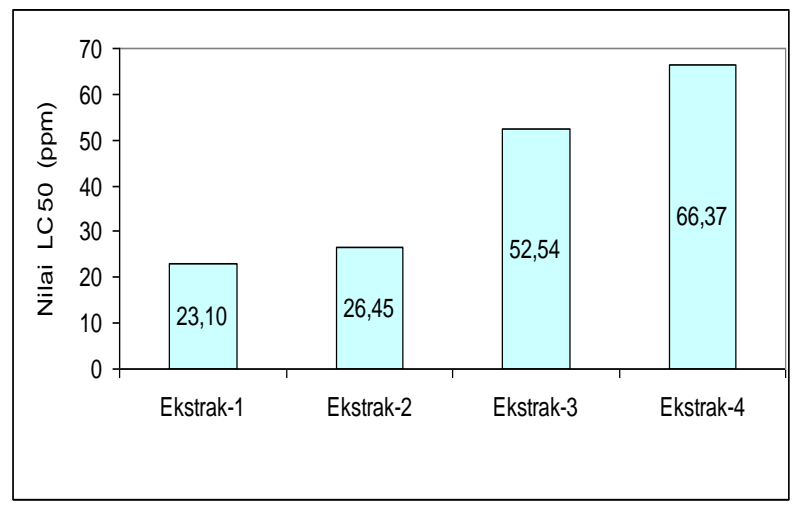

Keterangan:

- Ekstrak-1 adalah ekstrak yang langsung diaplikasikan berasal dari simplisia yang langsung diekstraksi

- Ekstrak-2 adalah ekstrak yang disimpan satu bulan sebelum aplikasi berasal dari simplisia yang langsung diekstraksi.

- Ekstrak-3 adalah ekstrak yang langsung diaplikasikan berasal dari simplisia yang disimpan satu tahu nsebelum diekstraksi.

- Ekstrak-3 adalah ekstrak yang disimpan satu bulan sebelum aplikasi berasal dari simplisia yang disimpan satu tahun sebelum diekstraksi

Gambar 2. Toksisitas fraksi ekstrak-etanol dari daun jayanti menurut variasi bentuk penyimpanan

(Sumber: Suripto, 2021)

\section{Apresiasi Petani Desa Bunut Baok Lombok Tengah Terhadap Tanaman Jayanti}

Sebelum dilaksanakan IbM ini, petani di Desa Bunut Baok Lombok Tengah tidak memilik apresiasi yang memadai terhadap tanaman jayanti. Hal ini karena selain tidak mengenal lebih banyak tentang identitas serta ciri dari tanaman jayanti, para petani juga tidak memiliki pengetahuan tentang manfaat tanaman jayanti sebagai sumber bahan molusisida yang dapat digunakan untuk mengendalikan keong mas hama tanaman padi.

Para petani hanya mengetahui bahwa daun tanaman jayanti tidak dapat dimakan seperti daun turi, kayunya tidak banyak, dan kanopinya tidak besar dan tidak rimbun sehingga tidak menarik untuk dijadikan sebagai pohon pelindung di sawah. Dengan demikian, sehingga para petani selama ini 
tidak memiliki minat untuk mengembangkan tanaman jayanti sebagai tanaman pelindung di sawahnya.

Berdasarkan hasil survey langsung dan hasil wawancara dengan petani, di Desa Bunut Baok tidak dapat dijumpai adanya tanaman jayanti baik di sawah maupun di pekarangan rumah. Menurut Suripto (2019a), di Pulau Lombok Nusa Tenggara Barat tanaman jayanti baru dapat diketemukan keberadaannya dengan kemelimpahan sedang di daerah pesawahan di Desa Gondang Lombok Utara.

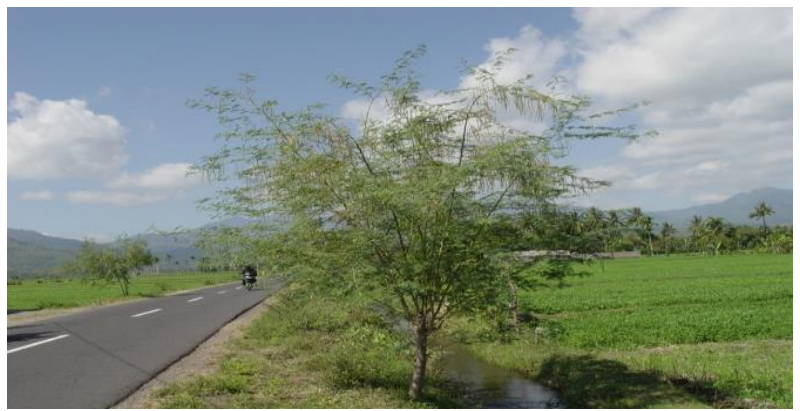

Gambar 4. Tegakan tanaman Jayanti yang masih dapat dijumpai di Desa Gondang Lombok Utara

Di Pulau Sumbawa, tanaman jayanti baru dapat dijumpai keberadannya sebagai tanaman liar di daerah rawa di Jereweh Sumbawa Barat, dan oleh petani setempat, tanaman jayanti ini disebut sebagai turi rawa.

Sebelum kegiatan IbM, para petani di Desa Bunut Baok sudah mengetahui adanya masalah hama keong mas, yang dapat merusak tanaman padi di sawah. Para petani juga sudah mencoba melakukan pengendalian keong mas tersebut dengan menggunakan pestisida dari bahan kmia sintetik di sawahnya, namun hasilnya tidak memuaskan. Keong mas tetap dapat diketemukan di sawah dan merusak tanaman padi, terutama semai dan tanaman padi muda hingga berumur kurang dari 20 hari setelah tanam.
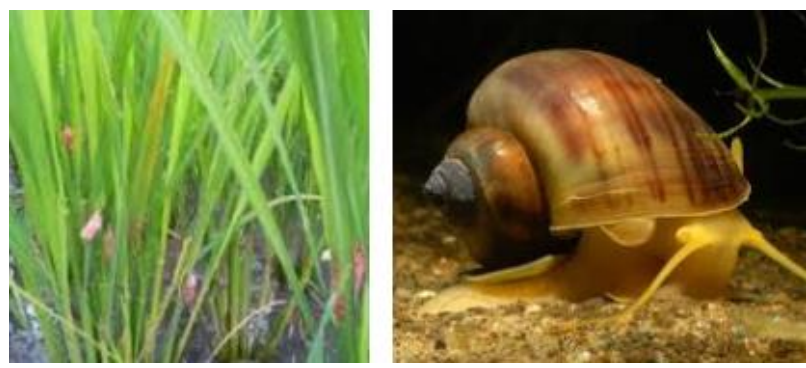

Gambar 5. Keong mas hama tanaman pdi
Setelah kegiatan IbM ini dilaksanakan, petani Desa Bunut Baok Lombok Tengah memiliki apresiasi yang tinggi terhadap tanaman jayanti sebagai tanaman sumber bahan molusisida untuk pengendalian keong mas hama tanaman padi.
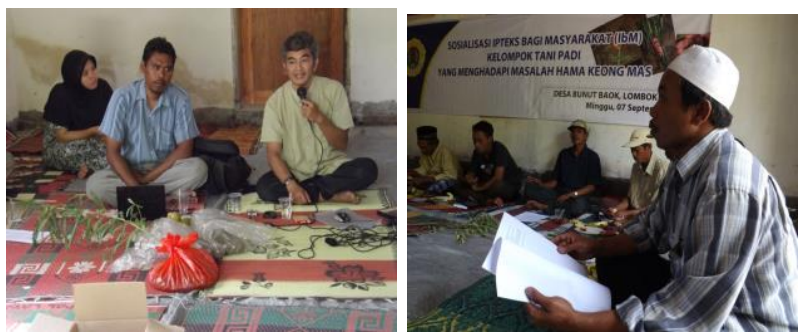

Gambar 6. Apresiasi petani terhadap tanaman jayanti meningkat setelah mengikuti kegiatan IbM.

Para petani juga memiliki minat untuk mengembangkan tanaman tersebut sebagai tanaman pelindung di sawahnya. Hal ini terbukti dari tingginya skor minat petani akan pengemabngan tanaman jayanti hasil wawancara dan dari besarnya prosentase jumlah petani yang melaksanakan penanaman bibit jayanti dengan menggunakan anakan dan biji jayanti yang diperoleh pada kegiatan IbM ini.

Kegiatan IbM ini juga menghasilkan luaran berupa 1) Buku Panduan Pembuatan dan Penggunaan Molusisida Jayanti untuk Pengendalian Keong Mas Hama Tanaman Padi, 2) draf artikel ilmiah, 3) semai jayanti yang ditumbuhan dari biji oleh petani, dan 3) pengembangan diktat mata kuliah Ekologi Tumbuhan.

\section{Kesimpulan}

Dalam skala percobaan, 1 ppm larutan daun jayanti terbukti efektif mematikan keong mas dan fesible bagi petani Desa Bunut Lombok Tengah untuk mengendalikan keong mas hama tanaman padi. Kegiatan IbM telah meningkatkan apresiasi petani di Desa Bunut Baok terhadap tanaman jayanti, meningkatkan pengetahuan dan keterampilan petani dalam pembuatan dan aplikasi bahan molusisida dari tanaman jayanti untuk mengendalikan keong mas hama tanaman padi.

Larutan daun jayanti untuk pengendalian keong mas hama tanaman padi sebaiknya diaplikasinkan langsung tanpa disimpan terlebih dahulu melibi 24 jam. Penyimpanan bahan 
molusisida dari tanaman jayanti dapat dilakukan terhadap bahan dalam bentuk serbuk kering daun untuk penyimpanan maksimal satu tahun sebelum aplikasi atau terhadap bahan dalam bentuk pasta ekstrak untuk penyimpanan maksimal satu bulan.

\section{Ucapan Terima Kasih}

Penulis menyampaikan terima kasih yang setinggi-tingginya kepada Direktorat Riset dan Pengabdian Masyarakat, Direktorat Jenderal Penguatan Riset dan Pengembangan Kementerian Riset, Teknologi dan Pendidikan Tinggi atas dukungan dana yang telah diberikan melalui Skema Program Kemitraan Masyarakat. Penulis juga menyampaikan terima kasih kepada Ketua Lembaga Penelitian dan Pengabdian Kepada Masyarakat Universitas Mataram dan Kepala Desa Bunut Baok Kabpupaten Kombok Tengah atas dukungan fasilitas dan kerjasamanya.

\section{Daftar Pustaka}

Francis,G., Kerem, Z., Makkar, H.P.S. \& K. Becker (2012). The biological action of saponins in animal systems: A review. British J. of Nutrition. 88: 587-605.

Munandar, A. (2013). Serba-serbi Keong Murbei dan Keong Mas. Laporan tidak dipublikasikan. Balai Penelitian dan Pengembangan Zoologi. LIPI. Bogor.

Suripto (2018). Evaluasi sifat anti moluska dari tanaman jayanti (Sesbania sesban). J. Gema Rinjani. 3(3):22-27.

Suripto (2009). Preferensi dan kecepatan makan dari keong mas terhadap tanaman padi. PIJAR MIPA. 4(2): 80-84.

Suripto (2019). Selektivitas anti moluska dari tanaman jayanti \{Sesbania sesban (L.) Merr.\} J. Biologi Tropis. 10(1): 24-32.

Suripto (2021). Stabilitas anti moluska dari tanaman jayanti \{Sesbania sesban (L.) Merr.\}. Laporantidak dipublikasikan. Lembaga Penelitian dan Pengabdian Kepada Masyarakat Universitas Mataram.

Suripto, Jupri, A. \& G. Tresnani (2015). Spektrum efek toksik dari berbagai fraksi ekstrak daun jayanti (Sesbania sesban) terhadap keong mas hama tanaman padi. J. Biologi Tropis. 8(1): 15-20. 